\title{
Synthetic Peptides E-PRA And E-PSM Vaccine
}

National Cancer Institute

\section{Source}

National Cancer Institute. Synthetic Peptides E-PRA And E-PSM Vaccine. NCI Thesaurus.

Code C67098.

A cancer vaccine consisting of E-PRA and E-PSM, two synthetic peptide analogs of PRAME (PReferential Antigen MElanoma) and PSMA (Prostate Specific Membrane Antigen), with potential immunostimulating activity. Upon direct administration into lymph nodes, synthetic peptides E-PRA and E-PSM vaccine may stimulate a cytotoxic Tlymphocyte (CTL) response ag ainst PRAME- and PSMA-expressing tumor cells. PRAME and PSMA are tumor-associated antigens upregulated and expressed on the cell surfaces of certain tumor cell types. 